\title{
CONFLICT AND HARMONY BETWEEN ISLAM AND LOCAL CULTURE IN REYOG PONOROGO ART PRESERVATION
}

\author{
M. Irfan Riyadi, Anwar Mujahidin, Muh.Tasrif \\ STAIN Ponorogo \\ Email: tasrif@stainponorogo.ac.id
}

\begin{abstract}
Reyog as performing art procession already existing in Ponorogo since pre-Islamic era still grows today even expanding outside the region of Ponorogo both regionally, nationally, and internationally. Reyog at the present time is generally acknowledged as cultural identity of Indonesian nation. The case is different from other Javanese traditions such as 'kentrung', 'ludruk', and 'ketoprak' that have collapsed over time. This fact raises interesting questions of how Reyog could withstand against the onslaught of various cultures that come to attack it from time to time. This study uses anthropological approach by utilizing the theory of Robert Redfield on the interaction of great tradition and little tradition. The results of this study indicate that although Reyog has interacted with various cultures, particularly Islam, it is able to reform and reformulate its tradition and find cultural attitudes flexible with various cultures that come with it. The cultural attitudes embody in stage-modernization, transformation of mysticalologies and reforms of the symbols of social values.
\end{abstract}

Reyog sebagai seni pentas arak-arakan yang telah ada di Ponorogo semenjak praIslam masih berkembang hingga saat ini bahkan terus mengalami perkembangan ke luar daerah Ponorogo baik secara regional, nasional, dan internasional. Reyog pada masa sekarang secara umum diakui sebagai identitas budaya bangsa Indonesia. Kenyataan itu berbeda dengan tradisi Jawa lain yang telah runtuh dan tinggal dalam arkeologi sejarah budaya seperti kentrung, ludruk, dan ketoprak. Keadaan ini menimbulkan pertanyaan menarik tentang bagaimana 
Reyog bertahan dari gempuran berbagai budaya yang datang menyerangnya dari zaman ke zaman. Penelitian ini menggunakan pendekatan antropologi dengan memanfaatkan teori Robert Redfield tentang pertemuan tradisi besar dan budaya kecil. Hasil penelitian ini menunjukkan bahwa meskipun Reyog bertemu dengan berbagai budaya, khususnya Islam, Reyog mampu mereformasi dan mereformulasi tradisinya sehingga ditemukan sikap budaya yang lentur dan cocok dengan berbagai budaya yang datang bersamanya. Sikap budaya itu berbentuk modernisasi pentas, transformasi mitologi, dan reformasi melalui simbol-simbol nilai sosial kemasyarakatan.

Keywords: local culture; Reyog; preservation; Islamic culture; integration

\section{Introduction}

Reyog is Ponorogo local culture and known as cavalcade performing art presenting a masked giant tiger with peacock's feather accessory on its upper part called dadak merak. This cavalcade is preceded by warrior knight leader called Klana Sewandono and followed by dancers of Jathilan, Bujang Ganong, and Penthul Tembem. This performing art is also accompanied by gamelan sound that generates spirit and song from trumpet that inflict mystique stimulation and attraction (Maryaeni, 2008: 84).

Reyog art could withstand across decades, since ancient Java, HinduBuddhism, until Islamic era. In Ponorogo, Reyog culture could make sustained symbiotic relationship with various newcomer cultures that attack its existence. In Dutch and Japanese colonialism era, Reyog had ever been prohibited due to its function as media gathering of many people that was feared to be association event against colonialism government. Nevertheless, such prohibition did not lead Reyog to extinction, and even after Indonesia got its freedom on August 17th 1945 and in multiparty era in 1955, Reyog developed into unifier media for political organizations. Several Reyog Ponorogo associations emerged such as BREN (Barisan Reyog Nasional/National Reyog Front), CAKRA (Cabang Kesenian Reyog Agama/Religious Reyog Art Branch), BRP (Barisan Reyog Ponorogo/Reyog Ponorogo Front), and KRIS (Kesenian Reyog Islam/Islamic Reyog Art). As Indonesian Communist Party (PKI) rode Reyog art, GajahGajahan and Unta-Untaan art emerged as counter and hedge of PKI Reyog force at that time (Ponorogo Level II Regional Regency Government, 2013: 5).

CAKRA (Cabang Kesenian Reyog Agama/Religious Reyog Art Branch) Reyog art gallery from traditional Islamic group is evidence for dialectic 
existence in Islamic environment to accept Reyog art existence. Nevertheless, between Islamic groups, there were groups rejecting Reyog existence, as Reyog performance was full of magical elements containing superstitious and mystical things. These groups subsequently created the art to compete with the fame of Reyog, namely Gajah-Gajahan and Unta-Untaan art (Mukarromah \& Devi, 2013: 67-68).

In its development, magical elements in Reyog performance could eventually be eliminated by several Reyog art activator. Reyog development is also supported by "rationalization" process, the waning of Reyog rituals rejected by Islamic circles. Rituals inviting supernatural force that initially performed before Reyog performance are now abandoned by partly Reyog art groups (Pratala, 2010.). The waning impact of magical elements in Reyog performance are the growth of Reyog art galleries in schools either in elementary, secondary or higher education level. Reyog is performed by children and adult by depending on physical strength maintained from physical exercises, instead of their magical strength.

Reyog develops into local original performing art favored by wide community: not only Ponorogo community but also international one. Ponorogo local government organizes International Reyog Festive every month of Syuro (Javanese Calendar) and Reyog performs every full moon night to provide opportunity and award for Reyog galleries grew in various regions outside Ponorogo, even from foreign countries.

It is said that Reyog art preservation reflects the existence of cultural dialogue, an effort to create cultural synthesis between local culture and newcomer culture. Such cultural behavior is called by Robert Redfield in his theory of great tradition and little tradition as cultural traditional dissemination (Redfield, 1956: 40-41). Dissemination capability could occur due to flexible cultural attitude and cultural elites capability (in this matter Reyog activator) to acculturate with bigger newcomer tradition. Incapability to conduct cultural dialogue shall lead tradition into its end into perished past archeology. Such matter occurs to kentrung, ludruk, ketoprak art and many others. Reyog art endurance in the middle of its conflict with Islamic culture and its preservation until present day is full of local genuine content that is interesting to examine.

Problems focus reviewed in this article are: 1) Ponorogo Islamic community relation with local cultures in Reyog, 2) Ponorogo Islamic community's meaning toward symbols in Reyog art and vice versa, and 3) form of Islamic community 
dialogue and Reyog activator to maintain Reyog art preservation and its heritance from generation to generation. Such review is expected to be useful as thought contribution in cultural anthropology and religion study field, especially in analyzing the academic actualization and religious contextualization with cultural values of certain regions.

\section{Literature Review and Conceptual Framework}

Discussing Reyog art, there are several research ever conducted previously. Amongst them is Pratala research which found that the mystique in Reyog art was no longer found recently (Pratala, 2010: 1). Another research described that the important role of Reyog art is to attract mass for political party, since 1955 election as PKI and PNI (Indonesian National Party) became parties with the most followers. Such matters impacted adversely toward Reyog art group, namely Reyog art group dismissal that previously used by PKI (Mukarromah \& Devi, 2013: 1). Meanwhile, Utomo (2004) explained about gemblak in Ponorogo Reyog art. Gemblak serves as jaranan or Jathilan dancer (braid horse dancer) that provokes the magical power of Warok. From these three research, Reyog position as art representing community customs are yet to attain attention, especially as dialogue system and symbolic system that store integration values so that Reyog art still preserves until today.

Culture always develops alongside human moral, power and creativity development. In its development, a culture frequently encounters and faces other cultures, creating inter-cultural dialectic. According to Redfield (1956: 40-41), such cultural encounter is not always in equal position: cultural encounter frequently occurs between local culture and central culture. Culture could survive as local culture which intensively communicates with local community thought that become its supporting pillars. Local culture community subsequently communicates with central culture outside themselves. Such culture shall become open and flexible and the attitude makes it able to collaborate with various kind of incoming culture. According to Kroeber (1948: 292) culture consists of three components: system from ideas and concept (eideos), set of action and patterned human activity (ethos) and material culture (Koentjaraningrat, 1995: 203-204; Taylor, 1958: 1).

Reyog art old tradition has rooted in community and formed culture and view of life. As it grows together with big tradition coming from Islam, inter-cultural contact occurs. In this point, Reyog art needs flexible cultural system in order to survive. This flexible culture comes from Ponorogo elite 
community either from Islamic environment or Reyog environment to make dialogue so that Reyog is preserved and accepted by entire community. Despite its rigid and hard attitude, an art shall slowly perish by stronger culture, for instance the art performance such as kentrung, ludruk and ketoprak that are extinct nowadays.

\section{Reyog Ponorogo History}

Reyog is a unique art from Ponorogo. Generally, Reyog consists of giant tiger mask with peacock's feather accessory on its upper part called dadak merak, a masked man playing role as Prabu Kelono Sewandono, a masked dancer playing role as Patih Bujangganong, and four horse dancers usually known as jathil. In addition, there is Reyog group of masked comedian, which known as pentulan. There are also musical instrument players consist of five or six players, with several musical instruments, gong, kethuk, kenong, kendang, angklung, and trumpet (Loelyadi, 1986). Gamelan accompaniment in Reyog performance is so unique with its spirit generating tone, and stimulation and attractiveness induced song.

Reyog performance generally describes Bantar Angin King who proposed the daughter of Kediri King, Dewi Sanggalit, but ended in failure. Reyog art existence is estimated since Hindu era. According to some folklore, there are several origin versions of Reyog art. First, Reyog comes from Wengker kingdom in Hindu era. Reyog was created by Mpu Bajang Anung that is called as Pujangga Anom, Bujangganong or Ganongan in Reyog story. Reyog was created to be presented for marriage requirement from Dewi Sanggaramajaya, which in folklore also known as Dewi Sanggalangit. She was known in cultural history as ascetic and also known as Dewi Kilisuci (Moelyadi, 1986: 106).

Second, Reyog Ponorogo which originally called as Barongan was a satire of Demang Ki Ageng Kutu Suryongalain against Majapahit king of Prabu Brawijaya V (Bhre Kertabumi). The satire was about the king that was yet leading his kingdom tasks fairly, ordinarily and sufficiently, and his power was influenced and controlled by his queen. Satire method was considered as a soft way to remind the leader. In Reyog, the king is associated as tiger overpowered by peacock as the symbol of queen (Ponorogo Level II Regency Government, 1996: 4).

Third, in early stage of the spreading of Islamic teaching, Ki Ageng Mirah (who subsequently became Batoro Katong loyal companion) still preserved Barongan as mass unifier and collector. With precise creativity and manipulation, 
Ki Ageng Mirah created a legendary story, the creation of Bantarangin kingdom with its king Kelono Sewandono (Klana wuyung) who was in love. These creative works of Ki Ageng Mirah spread in Ponorogo community and even believed as real story (Ponorogo Level II Regency Government, 1996: 4-5).

Batoro Katong arrival as a messenger from Demak to disseminate Islam in region between Lawu Mountain and Wilis Mountain (Ponorogo and surrounding region nowadays), did not diminish Reyog art. His success in securing part of Majapahit kingdom region and in disseminating Islamic religion peacefully emerged idea to keep preserving Reyog art. Reyog was preserved for Islamic missionary endeavor by giving new meaning. Reyog is representation of human journey into excellent ending. As a new meaning of Reyog Ponorogo existed since Hindu era, Batoro Kanong added the mark by giving a strand of prayer beads in the edge of Peacock's beak in dadak merak. Meanwhile the snake symbol is still remained (Ponorogo Level II Regency Government, 1996: 5).

Several sources above tell that Bantar Angin's version is believed to be the most valid one by most of Reyog Group in Ponorogo, though differences exist in its story flow. Elders of four Reyog groups that researcher interviewed, Singopotro Group of Kertosari Urban Village, Singo Mudho Group of Pakunden Urban Village, Mangun Kusumo Group of Mangunsumon Urban Village, and Singo Mudho Group of Grogol Sawo Village, believe that in a region nowadays known as Ponorogo Regency, there is a kingdom named Bantar Angin with the kings, Kelono Sewandono and Patih Bujangganong. They did not tell the occurence of Reyog is part of Prabu Kelono Sewandoni story that desired to propose princess of Kediri.

Legend concerning the origin of Bantar Angin Kingdom could be used as a reference studying magical science with a certain obligation for every male in Ponorogo. Pride of Ponorogo people do not lie in material richness, but in science they mastered. These beliefs have been valid started from their ancestors. This legend was in Kediri Kingdom era (Sudikan, 2014).

\section{Reyog Performing Model}

Reyog performance in ancient time was generally played in the afternoon, though it was not impossible to perform it at night, in open place. Reyog Ponorogo performance was also frequently carried out while walking in village road or big road. There are several versions concerning the origin of Reyog performance. According to Soemarto (2014), there are at least three 
versions of Reyog performance. First version assumes that Reyog comes from Bantar Angin kingdom story with Prabu Kelono Sewandono who desired to propose Dewi Songgolangit and ended with failure. According to this version, Reyog has groups of dancers which consist of Kelono Sewandono, Bujang Ganong, Barongan, and Jathilan. Jathil dancers must be boys in order to reflect masculinity and strength of soldier figure. In addition to male Jathil dances, other figures namely Penthul and Tembem are also maintained as the courtiers of King Bantarangin. These courtiers are giving entertainment as Reyog art group during their break.

Second version assumes Reyog as a satire from Majapahit community, namely Ki Demang Kutu Suryongalaman in Surukubeng, Wengker (Ponorogo) to his king Prabu Brawijaya V. This Surukubeng art version is only played by two figures, Barongan and Jathilan. Jathil dancers are played by boys (gemblakan) with female kebaya clothing as part of satire. Storyline concerning Kelono Sewandono's proposal toward Dewi Songgolangit do not exist. Therefore, this art version use Barongan name instead of Reyog.

The third one is Batorokatong version in Ponorogo Islamization era. During Batorokanong era, Reyog was utilized as missionary endeavor so it was given explanation based on Islamic teaching as human journey into good end of life. This Reyog version is almost similar with Bantar Angin Reyog version. The most notable difference lied only on dadak merak, in which the peacock has prayer beads and blossoming tail as symbol of Batoro Katong holding tasbih. Such form represents that Batoro Katong could control Ki Ageng Kutu (Wengker).

In September 24th, 1992, a workshop was organized to standardize Reyog art basic movement. Workshop was attended by Ponorogo community figure, especially Reyog art activator, cultural figure and local government element represented by Ponorogo Regency Education and Cultural Department representative. According to Slamet, Education and Cultural Department supervisor, who also attended the workshop, the forum had standardized Reyog art basic movement based on Bantar Angin Reyog version. Bantar Angin version was elected as this version deemed to be the most popular one in Ponorogo community and could easily followed and developed as well from its musical accompaniment, dance movement, and cosmetic aspects. The forum also resulted a book namely Pedoman Dasar Kesenian Reyog Ponorogo (Reyog Ponorogo Basic Art Guidance) which also known as yellow book (Interview with Slamet, November $\left.19^{\text {th }}, 2015\right)$. That book subsequently becomes guidance for festival 
and Reyog performance competition carried out every Muharram (Ponorogo Regency Government, 2013).

\section{Reyog Ponorogo Art Function}

Reyog develops from street art called obyogan reyog into stage art. Obyogan Reyog art existed in rural area performing appearance with no fixed pattern. Its appearance could utilize house yards, street road intersection or fork to be the art stage. Besides, Reyog art performance has experienced some modification and being adjusted with present condition. Reyog art generally serves the following function.

\section{Reyog as Ritual Means}

Two interviews were done on the ritual means of Reyog. According to Mbah Kotrik, most Reyog predecessor believed the existence of Barongan watchman so that all Reyog players must conduct ritual to ask for blessing and presenting such spirit before the commence of performance. Such ritual was critical to ensure Reyog performance smoothness and festivity.

Mbah Sarnu, Reyog art activator from Singopatran Group, also acknowledged the existence of such Barongan spirit. Several Reyog art activator groups come to a historic place to discharge with the spirit of Singo Potro before the commencement of Reyog (Interview with Mbah Sarpu, October 10th, 2015).

Barongan performance has various names, such as Barong Macan (tiger), Barong Bangkal (wild boar), and Barong Gajah (elephant). Barong and sang Hyang which is performed in Bali share the same function, as community protector mystical creature (Soedarsono, 2010: 14-15). Reyog Performance is started by inviting Barongan spirit. Such ritual still holds important role until present day in many sacred events, such as bersih desa, which is done to cleanse such village from disturbing evil spirits. Such activity is preserved until nowadays especially in Central Java villages in order to get the fortune, prosperity, and the whole safety for the entire village community. Reyog performance presented in the event serves as means to unify the village community.

\section{Reyog as Cultural Identity}

According to Geertz, pattern of understanding or meaning completely integrated in symbols and transmitted historically, and also system concerning concepts inherited into symbolic form, in which human could communicate, preserve and develop their knowledge and attitude against life. Such cultural 
concept plays important role as connector between human knowledge system and their life (in Abdullah, 2002: 1-2). Basic problems in human life concern either life nature or way of life into patterned symbols that become cultural elements, such as language, religious and arts.

Reyog Art is symbolic system constructed by Ponorogo community as reflection of concept knowledge inherited up to present days. Legend and folklore concerning Reyog contain values of community struggling, epic, love, self-esteem, and togetherness in facing life problems. They put Reyog as their cultural identity so that wherever they might be, they will remain preserving Reyog as their togetherness and struggling symbols as Ponorogo indigenous people.

\section{Reyog as Mass Mobilizer}

There is a theory of mass mobilization that Ponorogo political expert should comprehend: one who could make use of Reyog attractiveness could conquer Ponorogo mass. Reyog could generate huge mass causing several political parties in 1955 to gain huge support from community. Reyog role in mass mobilization is even increased as political party with Reyog achieving huge support and votes (Mukarromah \& Devi, 2013).

Reyog's relation with political party remains exist until reformation era nowadays. Reyog group could collect mass mostly from middle low class community gathered in coffee shop. Furthermore, Reyog groups also require funding support to maintain tools and performing regular practice. As explained by Singomudho Reyog, a group leader of Grogol village, the group got a set of Reyog gamelan instrument from one of East Java Regional House of Representative of Ponorogo Election Region (Interview with Sarengat, November $7^{\text {th }}, 2015$ ).

\section{Reyog as Entertainment Media (Aesthetic)}

According to Reyog group predecessor, Reyog has become art group serving for tanggapan (invitation) from long time ago as entertainment media for certain celebration agenda such as marriage, circumcision, and postharvest. Resident having the celebration agenda invite Reyog group performed in house yards. In old days, such Reyog performance was frequently followed with alcohol drink. Nowadays, alongside with Reyog group player's awareness to stay away from alcohol, the performance is accompanied by religious events, 
for example Reyog performance in the evening before the commemoration of prophet maulid in mosque or Islamic school.

Reyog as entertainment media nowadays develops more creatively into Reyog Festival. Reyog Group performance's pattern is determined by Tourism Department, making it better-of new creation dance. For example, Jathilan dance that is initially only played by four people, now it could be played by eight to twelve people, likewise warok dance. This festival presents Reyog art as worth watching show and could be played by the entire elements.

\section{Ponorogo Islamic Community Response toward Reyog Art}

Reyog art elements that did not reflect Islamic value made Reyog art activator concentrated just on community called tiyang ho'e. Tiyang ho'e are Reyog art activators consist of people claiming themselves as Moslem but do not carried out worship actively and not comply with sharia rules, except life cycle rituals such as celebration, tahlil, and yasinan. They spiritually followed ancient Javanese school, such as contemplation, imprisoned, white fasting rituals and many others to attain power, magical strength, or safety. They like to collect power from talisman, especially those that could be inserted into black suit or striped shirts they usually wear. It was only a few of Reyog art activator from tiyang mesjid or mosque community or student group (santri) (Achmadi, 2013).

Relationship between tiyang ho'e and tiyang mesjid actually did not inflict conflict or hostility that caused crisis or even chaos. There were still good communication between them as shared myth concerning village danyang (spirit). Figure associated as village danyang in Grogol village and Kauman village are the graveyard of kiai or people disseminating Islam for the first time in such village. Abangan and student group met and having shared tradition to respect village danyang in bersih desa event. In addition of village danyang respecting tradition, they also have the similar tradition of respecting their ancestor spirit. In Javanese customs there is slametan (celebration) for the third day, seventh day, fortieth day, hundredth day, and thousandth day for the deceased people. Each celebration either carried out by santri or abangan group always filled with dzikir tahlil consist of prayers and al Quran recitation to pray for the spirit of the deceased. This event is also accompanied by various foods, such as tumpeng rice, grilled chicken, and apem cake with their special meaning (Kuntowijoyo, et al., 1987). In this celebration both the Reyog activator and mosque community are gathered. 
Aside from village danyang and ancestor honor tradition above, student and abangan group are separated in performing their respective life pattern and culture. Each group has different way of life resulting different knowledge and life style as well. Student group in Grogol village develops the musical art namely hadrah and kompangan using rebana instrument and sholawatan song. Such musical group could perform in religious event such as al Quran Recitation in commemoration of Prophet Maulid and Isra' Mi'raj. Kompangan group also usually performs based on invitation or request for family celebration such as circumcision, aqiqah, or wedding reception.

Abangan group develops Reyog art as life pattern expression that is free from religion boundary norms. They could play Reyog from afternoon into evening, something deemed as time wasting by mosque community. On the other side, that activity is considered normal for Abangan group as they have no sin feeling to abandon Ashar and Maghrib pray. They even use night time for practicing Reyog from Isya until late at night.

Another element of Reyog art separating tiyang ho'e and tiyang mesjid is Jathilan dancer. Before 1980s, Jathilan dancers were men with woman makeup, known as gemblak. Gemblak in daily life wore tight short, blue glasses, and hat. After 1980s, Reyog group were multiplied as outside city performance increased. Consequently, it was getting more difficult to find jathil player from male youngster. Innovation emerges: jathil dancer from female youngster. This change was initially rejected by Ponorogo Regency Education and Cultural Department as that innovation deemed deviant from Reyog art pattern. Reyog elders, such as Mbah Wo Kucing, were also disagree with female jathil dancer as they maintain hereditary tradition (Interview with Mbah Daman, November $\left.14^{\text {th }}, 2015\right)$.

Female jathil dancers are critical contribution in Reyog Festival development. They make Jathilan dance not only limited in four people, but could be played by eight to twelve people. Jathilan choreography practice is increasingly developing with various performances on stages.

Other phenomenon that is not from Reyog art element, but frequently encountered in obyog Reyog performance is alcohol. Players and partly the audience play Reyog while drinking alcohol. Sarengat, leader of Singo Mudho group of Grogol Village, found it difficult to prevent his team players from alcohol. With covering tone, Sarengat explained that alcohol only be used in moderation to give spirit for his players (Interview with Sarengat, November $\left.7^{\text {th }}, 2015\right)$.

el Harakah Jurnal Budaya Islam Vol.18 No.2 Tahun 2016 
Female jathil dancer also becomes the gateway for pop culture in Reyog art. Nowadays it is said that many dancers completely break out from basic pattern. Jathil dancer no longer use jaranan (hobbyhorse). Formerly, they wore trousers, white shirt from satin and big necklace covering their chest. Now their costume is also changed, becoming tighter and more transparent. The audiences even insert sum money inside their bra.

Such performance rose concerns within Ponorogo community, including from Reyog art circle themselves. Slamet, as former Reyog Festival cultural supervisor and artist, stated that jathil dancers are obliged to dressed properly during Reyog festival, otherwise they will be disqualified (Interview with Slamet Riyanto, November $\left.9^{\text {th }}, 2015\right)$. The same matter confirmed by Mbah Daman, an elder of Naom Pujonggo Reyog from Kauman Sumoroto village. As the founder of Pujonggo Anom Reyog group, he disagreed with jathil dancer shift from male to female, even dancing with no eblek or jaranan that could lower the hereditary pattern (Interview with Mbah Daman, November 14 ${ }^{\text {th }}, 2015$ ).

Tiyang mesjid (student group) in Ponorogo, especially from kiai elite circle, criticized dance art performance played by female. According to law, Moslems are obliged to control lust to the opposite sex. The Moslem would not respect female performing improperly like prostitutes.

Another conflicting Reyog art element with student group (tiyang mesjid) is sorenan, that is inviting unseen spirit, making barong dancers act as being possessed and having unusual strength. Nowadays, alongside with increasing community religious awareness and the popularity of student Reyog and Reyog Festival, sotrenan is infrequently practiced (Interview with Mbah Sarnu, October 10th, 2015).

Sotrenan element combined with alcohol made Reyog image in community so far as threatening traditional performing art. Such phenomena made certain distant separation between Reyog group and student group. The separation could prevent negative impact so they would not curse and disturb each other. Reyog group that is far from mosque environment could practice and make performance based on their desire without interfering mosque activity and vice versa. As explained by Khoiri and Syamsudin (Interview November $20^{\text {th }}$, 2015), Reyog group and the mosque community were on their own way: Reyog group did not interfere the praying and worshiping people. 


\section{Counter Art Emergence in Moslem Circle}

Islamic circle designed new parade art, namely gajah-gajahan and ontaontaan which were designed by student group in order to block PKI Reyog art domination since 1948 through 1965. Reyog activators were slaughtered due to 1965 PKI rebellion case. For several years Ponorogo Reyog art activity were vacuum meanwhile the new designed parade arts were more popular as Islamic parade tradition (Susanto, 2007: 225).

Gajah-gajahan art is traditional parade street consisting of group of dancer, musician, and singer. Its main figure is elephant-shaped big statue decorated like kingdom elephant, made of basket and wood wrapped with black cloth as big as real elephant. It is lifted by two people in the front and the back respectively like barongsai, but in this art its lifters are completely vanished inside the elephant statue. On top of elephant statue, young handsome boy sat and dressed just like prince, accompanied with an umbrella man.

The elephant statue is accompanied with escort to lead its path, accompanied with musical instruments such as jedor, kendang, kenong, kentrung, kecer, and tambourine. This statue is also surrounded by dancer and singer while singing salawat and praise accompanied by hadroh music. The dense Islamic nuance in this art comes from salawat music, its bedug and hadrah musical instrument.

In its current development, gajah-gajahan art develops into different way: dominated by female dancers and singers, its rider is beautiful girl, its music is also mixed by modern instrumental such as organ music, and also Javanese Campursari or dangdut song. Eventually, this gajah-gajahan art is also adopted by Reyog fan. Therefore, this parade is also carried out simultaneously with Reyog parade.

Onta-ontaan art is traditional parade street consisting of group of dancer, musician, and singer. Its main figure is camel-shaped big statue decorated like Arabic desert camel as lift for Middle East king. This statue is made of basket and wood wrapped with real camel shaped black cloth, lifted by two people on the back side of camel's feet, dancing along the way. Camel saddle seating is positioned on its back. This traditional art is ridden by turbaned young male similarly decorated with Arabic prince or syekh and accompanied with hadrah instrumental player with Middle East unique dryer cloth. Songs being played are Islamic song and verses that mostly in Arabic language.

el Harakah Jurnal Budaya Islam Vol.18 No.2 Tahun 2016 


\section{Reyog Art Integration and Preservation}

Community concerns on the development of Reyog on streets and parade art lead into workshop concerning Reyog on November 24th, 1992. Such workshop generated certain basic rule formulation of Ponorogo Reyog dance in form of book entitled Reyog Ponorogo Art Basic Guidance in Nation Cultural Performance. The basic guidance became the pioneer of performing Reyog, which is later known as Festival Reyog (Interview with Selamet Riyanto, in November $\left.9^{\text {th }}, 2015\right)$.

Reyog Festival art performing element emphasizes more on dance element that rely on aesthetic element to make the performance more interesting. Unfortunately, elements such as sotrenan and dayangan are abandoned. As a replacement all Reyog artists nowadays rely on regular practice. At least, for big event such as National Reyog Festival, committee will only arrange for celebration/tahlilan agenda and pray to ask for God's blessing for the sake of safety and smoothness during the competition (Interview with Mbah Kotrik, October $\left.10^{\text {th }}, 2015\right)$. Jathilan dance is also maintained from free dance out from its pattern that gives opportunity to its dancer to interact with spectators and opening the chance of eroticism, and even sexual harassment. With the touch of professional choreographer and art teachers at school, Jathilan dance performance is now full of innovation, variation, and attractiveness.

Reyog festival performance that emphasizes on aesthetic aspect lifted Reyog image in community. Such phenomenon was followed by the inception of student Reyog group, from Elementary School, Junior High School, Senior High School and even Higher Education level. Mosque group is also now more open toward Reyog Festival group. They are willing to invite Reyog to enliven religious events, such as Muhammad SAW Prophet Maulid. Miftahul Khoiri, Principal of Grogol Village Islamic Senior High School, gave his approval to invite Reyog Festival group to his school during guess visit from Japan. According to Khoiri (Interview November 20 ${ }^{\text {th }}$, 2015), Islam is not skeptical with Reyog, but Reyog activator attitude that shows behavior deviant from Islamic teaching itself that make mosque people are not so intimate with them. Positive reception arises from the existence of Reyog Festival group with students as its players.

Singopotro Reyog Group of Kertoasari Urban village, for example, could nowadays rise up with broader resident support. From religious practice aspect, Kertosari Urban Village, called as Singopatran area, are well known as Abangan area. By building the musholla in the middle of the area and the 
existence of newcomer consisting of employees and teachers with better and more developed religion understanding, resident in that area could interact in every religious event in musholla. Residents that become active supporting musholla activity are nowadays unified to rise Singopotro Reyog group. They allow their children to join the regular practice held every Saturday night. Thus, Reyog festival existence is purely changing from Ponorogo community, especially mosque group as well as tourism market demand.

\section{Meaning on Elements in Reyog Art}

Art is creative product of its community so that symbols exist in art wok elements store collective meaning of its community. Ponorogo community that preserves Reyog has world vision and values to preserve that are symbolized in Reyog art elements. Conflict in Ponorogo community reflected from Ponorogo Reyog art preservation is reflection of Ponorogo community with various values. Such groups have different way of life and purpose. Nevertheless, no significant conflict occurs among groups. Those groups even tend to interact and meet one another.

Reyog Ponorogo basic guidance book issued by Ponorogo Regency Tourism Department describes that the symbolical meanings of Reyog are patriotism and heroism which include:

Personal serenity, toughness, and rigidity;

Awareness to anticipate and full of consideration in taking decision;

Skillful, handy, and workmanlike in action;

Being loved, love, and responsive in social life; and

Respected and full of prestige (Ponorogo Regency Government, 2013: 21).

The above characteristics and values are in line with life purpose in Islamic teaching; creating interaction, meaningful to each other, and creating new value and symbol creations. Mbah Mangun, a Muhammadiyah figure behind the inception of Reyog group at Muhammadiyah Ponorogo university, stated that warok is similar with wira'i in Islamic concept. Wara' (Arabic language) concept had been taught by Prophet Muhammad and his companions, namely zuhud attitude toward world matter (Interview with Mbah Mangun Utomo, November $\left.3^{\text {rd }}, 2015\right)$.

The success key of warok is capability in controlling lust in one's life journey, namely natural lust symbolized with black, anger lust symbolized with red, and supiah lust symbolized with yellow color. Those three must be controlled with calmness symbolized with white. Mbah Mangun described the human struggle against lust to attain serenity by quoting Imam al Ghozali 
tasawuf thought: that human heart as source of goodness and serenity is associated with king and minds that associated as vice regent in a kingdom, whilst lust fluctuation is kingdom enemy. If a vice regent is loyal to the king and do everything he possibly could to attain king purpose, advanced and glorious kingdom. Otherwise, the kingdom shall ruin as it is controlled by the enemy, namely lust. Symbols demonstrated by Bujangganong in war against Singobarong interpreted as the vice regent loyalty to the king in order to attain kingdom's future goals.

As interaction result with student (santri) group, Reyog attains new meaning as riyaqun that closes to the meaning of riyadhun, though soul and though body (olah rogo) to create white-hearted people (qolbun salim) to attain insan kamil degree, which is called as warok by Ponorogo community (Interview with Mbah Mangun Utomo, November $3^{\text {rd }}$, 2015).

Reyog's new meaning as explained by Mbah Mangun is in compliance with the meaning according to folklore given by Batoro Katong, who disseminated Islam teaching in Ponorogo. Reyog shall be preserved for Islamic teaching by giving new meaning as human journey symbol into the good ending of life. As a sign for new meaning of Reyog Ponorogo that existed since Hindu era, Batoro Kanong adds the mark in form of a strain of chaplet at the edge of Peacock's beak with dadak merak, along with the snake symbol which is maintained until today.

\section{Conclusion}

There are positive and negative relation in Ponorogo Islamic community with Reyog. Positive relation is formed by Reyog functions as entertainment and social gathering media, whilst negative relation formed by syncretic mystical ritual culture exist inside Reyog art and wasting behavior that create tiyang mesjid and tiyang ho'e group.

Reyog art preservation carried out by several means: a) Reyog art modernization, especially through Reyog Festival and art galleries, b) new meaning of Reyog art symbols, c) world view inheritance as the soul of Ponorogo community.

Islamic group dialogue with Reyog art activator is Reyog art preservation effort carried out by Islamic positive meaning. It is done by eliminating mystical, time consuming, and alcohol drinking aspects by Reyog art activator. Accordingly, harmonious cultural encounter occurs to preserve Ponorogo Reyog art. Islamic group gives Islamic meaning on Reyog in mystical, color, tools, and Reyog instrument aspects which leads it into Islamic fundamental 
philosophy that could be utilized by Reyog activator, as well as Islamic group argumentation to accept Reyog art.

\section{References}

Abdullah, Irwan. 2002. Simbol, Makna dan Pandangan Hidup Jawa, Analisis Gunungan pada Upacara Garebeg. Yogyakarta: Balai Kajian Sejarah dan Nilai Tradisional.

Achmadi, Asmoro. 2013. Pasang Surut Dominasi Islam terhadap Kesenian Reyog Ponorogo. Jurnal Analisis 13(1), 111-134.

Koentjaraningrat. 1995. Pengantar Ilmu Antropologi. Jakarta: Aksara Baru.

Kroeber. 1948. Anthropology. New York: Harcout, Brace and Coompany.

Kuntowijoyo et. al. 1987. Tema Islam dalam Pertunjukan Rakyat Jawa: Kajian Aspek Sosial, Keagamaan, dan Kesenian. Departemen Pendidikan dan Kebudayaan, Dirjen Kebudayaan, Proyek Penelitian dan Pengkajian Kebudayaan Nusantara (Javanologi) 1986-1987.

Maryaeni. 2008. Metode Penelitian Kebudayaan. Jakarta: Bumi Aksara.

Moelyadi. 1986. Ungkapan, Sejarah Kerajaan Wengker dan Reyog Ponorogo. Ponorogo: Dewan Pimpinan Cabang Pemuda Panca Marga.

Mukarromah, Sururil \& Devi, Shinta I.S.R. 2013. Mobilisasi Massa Partai Melalui Seni Pertunjukan Reyog di Ponorogo Tahun 1950-1980. Jurnal Verleden 1(1), 67-68.

Pemerintah Daerah Tingkat II Kabupaten Ponorogo. 1996. Pedoman Dasar Kesenian Reyog Ponorogo dalam Pentas Budaya Bangsa. Ponorogo.

Pemerintah Kabupaten Ponorogo. 2013. Pedoman Dasar Kesenian Reyog Ponorogo, Dalam Pentas Budaya Bangsa. Ponorogo.

Pratala, Cita. 2010. Pudarnya Ritus Magis Kesenian Reyog Ponorogo. Undergraduate thesis submitted to FISIP UNAIR Surabaya.

Redfield, Robert. 1956. Peasant Society And Culture. Chicago: The University of Chicago Press.

Soedarsono, R.M. 2010. Seni Pertunjukan Indonesia di Era Globalisasi. Yogyakarta: Gadjah Mada University Press. 
Soemarto. 2014. Menelusuri Perjalanan Reyog Ponorogo. Ponorogo: CV Kota Reyog Media.

Sudikan, Setya Yuwana. 2013. Kearifan Lokal Dalam Tradisi Lisan Nusantara (Penggalian Nilai-Nilai Kebhinekaan Untuk Indonesia Masa Kini Dan Masa Depan). A paper presented in Seminar Nasional Tradisi Lisan dalam Pendidikan. Bali: Universitas Saraswati Tabanan - Bali, 26 - 27 April.

Sudikan, Setya Yuwana. 2014. Pola Dakwah Islam di Ponorogo. A paper presented in Seminar Jurusan Ushuluddin \& Dakwah. Ponorogo: STAIN Ponorogo, April.

Susanto SJ, Budi. (ed.). 2007. Sisi Senyap Politik Bising. Yogyakarta: Kanisius.

Taylor, Edward Burnett. 1958. The Primitive Culture. New York: Harper \& Brothers.

Utomo, Yoyok Prasetyo Dwi. 2004. Perilaku Gemblak Dalam Kesenian Reyog Ponorogo di Desa Sumoroto Kabupaten Ponorogo (Kajian Seksualitas dan Moral). Undergraduate thesis submitted to State University of Malang. 